\title{
SISTEM UJIAN ONLINE LISENSI UNTUK PERTOLONGAN KECELAKAAN PENERBANGAN DAN PEMADAM KEBAKARAN
}

\author{
Aris Martono**1, Sucipto $^{2}$, Ryan Maulana ${ }^{3}$ \\ ${ }^{1,3}$ Program Studi Teknik Informatika Fakultas Sains dan Teknologi Universitas Raharja \\ ${ }^{2}$ Program Studi Sistem Informasi STMIK Pringsewu \\ Email: *1aris.martono@ raharja.info, ${ }^{2}$ cipto.adam71@ gmail.com, ${ }^{3}$ ryan.maulana@ raharja.info
}

\begin{abstract}
Abstrak
Penelitian ini bertujuan untuk memudahkan ujian lisensi PKP-PK berjalan dengan baik dan benar pada PT. Angkasa Pura II (Persero). Ujian lisensi ini masih dilakukan secara manual termasuk dengan sistem koreksi ujian sehingga membutuhkan waktu untuk menilai ujian yang dilakukan oleh instructure / trainer. Adanya kemajuan teknologi informasi dan lalu-lintas penerbangan di udara semakin padat maka risiko kecelakaan penerbangan juga semakin tinggi. Dengan demikian hal ini membutuhkan tenaga kerja yang terampil dan profesional serta berlisensi PKP-PK untuk mengantisipasi munculnya risiko. Penelitian ini menggunakan metode survey, analisis kebutuhan elisitasi yang menghasilkan 20 kebutuhan fungsional dan 5 kebutuhan non-fungsional, dan melakukan perancangan sistem yang berbasis obyek disertai pembuatan prototype aplikasi system tersebut. Perancangan system ini terdiri dari proses list user, list kategori, list soal, list ujian/tes dan list hasil ujian dan disertai sistem database. Terwujudnya aplikasi system secara on-line ini, proses ujian bisa lebih cepat dan efisien, serta menghindari kecurangan dalam proses ujian bagi perserta pendidikan (karyawan) dan instruktur karena bisa langsung mengetahui nilai tanpa pengecekan jawaban ujian.
\end{abstract}

Kata Kunci — ujian online, lisensi PKP-PK, kecurangan proses ujian.

\begin{abstract}
This study aims to facilitate the PKP-PK licensing test running well and correctly at PT. Angkasa Pura II (Persero). This licensing exam is still done manually including the exam correction system so that it can no longer be used as a routine activity.

Instructors / trainers must increase working hours to make and assess exam questions for participants in education and training. With the advancement of information technology more rapidly and air traffic in the air is getting denser, the risk of flight accidents is also getting higher. Thus this requires a skilled and professional workforce and PKP-PK licensed to anticipate the emergence of risks. The research method used is by conducting surveys, elicitation needs analysis, and designing object-based systems and making system application prototypes. Discussion of the application of this system, namely designing a system consisting of a user list process, a list of categories, a list of questions, a list of test results with users such as education participants (employees), instructors and system administrators. Designing a data base system and making a prototype is to realize the on-line exam system application. With the realization of this system application, the examination process can be faster and more efficient, narrow cheating in the examination process, education participants (employees) and instructors can immediately check the grades without checking the test answers.
\end{abstract}

Keyword —online exam, PKP-PK license, cheating test process. 


\section{Latar Belakang}

\section{PENDAHULUAN}

Unit PKP-PK (Pertolongan Kecelakaan Penerbangan dan Pemadam Kebakaran), salah satu tugas pokok dan fungsinya adalah memberikan lisensi PKP-PK melalui pendidikan dan latihan dari PT. Angkasa Pura II (Persero). Untuk mendapatkan lisensi ini melalui sistem ujian lisensi secara manual demikian pula sistem koreksinya. Hal ini membuat trainer/instructure harus menambah jam kerja dalam pembuatan soal dan penilaiannya. Kemajuan teknologi informasi dan padatnya lalu-lintas udara maka risiko kecelakaan penerbangan juga semakin tinggi. Oleh karenanya dibutuhkan sebuah sistem ujian online sebagai solusi mengoptimalkan sistem ujian lisensi. Sistem ujian online diharapkan bermanfaat untuk mengurangi tingkat kecurangan peserta pendidikan dan latihan. Beragam soal yang disajikan dapat beragam dan berbeda satu dengan yang lain. Hal ini dapat menghemat waktu yang digunakan untuk mengoreksi ujian sesuai dengan kriteria sistem itu sendiri. Sistem ujian online ini juga memiliki manfaat finansial yaitu menghemat penggunaan kertas ujian. Penerapan sistem ujian online ini juga mampu meningkatkan mutu pendidikan dan pengajaran di masa mendatang.

Sistem ujian online ini menyajikan nilai atau skor yang dapat dilihat langsung setelah peserta selesai menyelesaikan ujian.

Oleh karenanya hal ini dapat diidentifikasi masalahnya sebagai berikut :

1. Bagaimana sistem ujian lisensi yang berjalan saat ini?

2. Apa kendala-kendala yang terjadi pada proses ujian berlangsung?

3. Apa perbedaan antara proses sistem ujian lisensi online berbasis web dengan proses manual pada PT. Angkasa Pura II (Persero)?

Adapun permasalahan yang dibahas dalam penelitian ini mencakup prosedur dalam menjalankan dan merancang ujian online berbasis web pada unit PKP-PK PT. Angkasa Pura II (Persero). Penginputan soal yang dilakukan instruktur untuk mengetahui hasil jawaban peserta secara online.

Tujuan penelitian ini adalah:

1. Untuk memudahkan ujian berjalan dengan baik dan benar pada PT. Angkasa Pura II (Persero) saat ini.

2. Untuk memudahkan instruktur mengetahui kendala yang terjadi pada saat proses ujian berlangsung.

3. Untuk menyusun rancangan dan membangun sistem ujian online di unit PKP-PK pada PT. Angkasa Pura II (Persero) sehingga prosesnya lebih teratur, efisien dan efektif.

Sedangkan manfaat penelitian ini adalah :

a. Membantu instruktur dalam melakukan ujian lisensi PKP-PK pada PT. Angkasa Pura II (Persero) saat ini.

b. Membantu mengatasi kendala-kendala yang terjadi pada saat ujian berlangsung.

c. Mempermudah proses dan membantu dalam ujian khususnya di PT. Angkasa Pura II (Persero).

\section{METODE PENELITIAN}

\section{Metode Pengumpulan Data}

Untuk mendapatkan data yang diperlukan dalam melakukan penelitian ini, maka digunakan metode pengumpulan data sebagai berikut:

1. Metode Pengamatan (Observation Research)

Berupa pengumpulan data melalui peninjauan secara langsung ke PT. Angkasa Pura II (Persero) dengan cara mengumpulkan data, informasi dan mempelajari catatan-catatan serta dokumen yang ada.

2. Metode Wawancara 
Dilakukan melalui proses tanya jawab kepada instruktur atau peserta diklat PT. Angkasa Pura II (Persero) dengan para stakeholder.

3. Metode Studi Pustaka

Pengumpulan data dengan cara membaca dan mempelajari buku atau literature yang berhubungan dengan penelitian ini, untuk dapat digunakan sebagai landasan teori dalam penelitian.

\section{Metode Analisis}

Suatu metode untuk analisis kebutuhan dalam rekayasa perangkat lunak ini menggunakan metode elisitasi.[1] Elisitasi ini didapat melalui proses wawancara dan dilakukan melalui tiga tahap yaitu:

1) Elisitasi Tahap I, Berisi seluruh rancangan sistem baru yang diusulkan oleh pihak manajemen terkait oleh pihak wawancara.

2) Elisitasi Tahap II, Merupakan hasil dari pengklasifikasian elisitasi tahap I berdasarkan metode MDI(Mandatory, Desireable. Inessential). Metode MDI ini bertujuan memisahkan antara rancangan sistem yang penting dan harus ada pada sistem.

3) Elisitasi Tahap III, merupakan penyusutan elisitasi tapah II dengan cara mengeliminasi semua requirement dengan option I pada metode MDI. Selanjutnya semua requirement yang tersisa diklasifikasikan kembali dengan metode TOE(Technical, Operational, Economic ).

4) Final Draft Elisitasi merupakan bentuk akhir dari tahapan-tahapan elisitasi yang dapat dijadikan acuan dan dasar pengembangan system yaitu terdapat 20 kebutuhan funsional yang difasilitasi di dalam sistem dan 5 kebutuhan non-fungsional yang difasilitasi di luar sistem.

\section{Metode Perancangan}

Dalam penelitian ini metode perancangan yang digunakan adalah metode yang berorientasikan objek melalui tahapan pembuatan menggunakan UML (Unified Modelling Language). Menggunakan visual paradigm for UML 8.0 Professional Edition. Pembuatan Database dan pembuatan program yang disesuaikan berdasarkan kebutuhan stakeholder pada daftar elisitasi. Program yang digunakan dalam pembuatan sistem menggunakan bahasa pemrograman PHPMysql sebagai database dan Adobe Dreamweaver CS3 sebaga interface aplikasi untuk mendesain tampilan sistem. Waterfall Mode untuk membangun sebuah perangkat lunak yang dimulai dengan mencari spesifikasi atau requirements yang dibutuhkan pengguna dan berkembang ke tahap berikutnya yaitu proses pengembangan perangkat lunak yang berurutan (sequential) dimana prosesnya dari atas ke bawah (seperti air terjun) melalui tahapantahapan yang harus dijalankan untuk keberhasilan pembuatan perangkat lunak. [2]

\section{KAJIAN LITERATUR \\ Ujian Online.}

"Exam is a (pick any of the following) tool, procedure, device, examination, investigation, assessment, or measure of an outcome (which is usually some kind of behaviour)". [3]

(Ujian adalah alat, prosedur, perangkat, pemeriksaan, investigasi, penilaian, atau ukuran suatu--yang biasanya merupakan semacam perilaku tertentu).

Dalam konteks akademis atau profesional, ujian adalah tes yang bertujuan untuk menentukan kemampuan seseorang. Biasanya ujian tes tertulis, walaupun beberapa mungkin praktis atau komponen praktis, dan sangat bervariasi dalam struktur, isi dan kesulitan tergantung pada subjek, kelompok usia orang yang diuji dan profesi. Pemeriksaan kompetitif adalah ujian di mana pelamar bersaing untuk sejumlah posisi, sebagai lawan hanya harus mencapai tingkat tertentu untuk lulus. "UJIAN adalah kegiatan untuk mengetahui seberapa tinggi tingkat keberhasilan siswa."

Online adalah terhubung, terkoneksi, aktif dan siap untuk operasi, dapat berkomunikasi dengan atau dikontrol oleh komputer. Online ini juga bisa diartikan sebagai suatu keadaan dimana sebuah device (komputer) terhubung dengan device lain, biasanya melalui modem. Online adalah sedang menggunakan jaringan, terhubung dalam jaringan, satu perangkat dengan perangkat lainnya yang terhubung sehingga bisa saling berkomunikasi. Berdasarkan teori online 
diatas dapat disimpulkan bahwa online adalah suatu keadaan dimana sebuah device (komputer) terhubung dengan device lain dengan menggunakan perangkat modem, sehingga bisa saling berkomunikasi.

"Computer Based Test (CBT) is assessments that are administered by computer in either stand-alone or dedicated network or by other technology devices linked to the internet or World Wide Web (WWW)".[4]

(Computer Based Test (CBT) adalah penilaian yang dikelola oleh komputer baik di jaringan yang berdiri sendiri atau berdedikasi atau oleh perangkat teknologi lain yang terhubung ke internet atau World Wide Web (WWW).

\section{Internet}

Salah satu bentuk media komunikasi dan informasi interaktif. Wujud internet adalah jaringan komputer yang terhubung di seluruh dunia. Internet digunakan untuk mengirim informasi anat komputer diseluruh dunia sehingga kita dapat bertukar informasi secara cepat disebut internet.[5]

Teknologi yang menghubungkan satu komputer dengan jutaan komputer lainnya di seluruh dunia sehingga bisa dimanfaatkan untuk mencari informasi, mengirim surat elektronik, berkirim foto, serta banyak lagi. Internet sering juga disebut dengan istilah dunia maya karena dengan internet kita bisa berhubungan dengan banayak orang dari seluruh dunia tanpa harus mengunjungi orang-orang itu satu demi satu disebut internet".[6]

\section{Lisensi}

Suatu bentuk hak untuk melakukan serangkaian tindakan atau perbuatan yang diberikan oleh mereka yang berwenang dalam bentuk izin. tanpa adanya izin tersebut, maka tindakan atau perbuatan tersebut merupakan suatu tindakan yang terlarang, yang tidak sah, yang merupakan perbuatan melawan hukum disebut lisensi.[7]

\section{Pertolongan Kecelakaan Penerbangan dan Pemadam Kebakaran}

Unit PKP-PK adalah unit bagian dari penanggulangan keadaan darurat di bandar udara pada PT. Angkasa Pura II.

\section{HASIL DAN PEMBAHASAN}

\section{Rancangan Sistem Ujian Online}

Ada beberapa prosedur oprasional yang dilakukan oleh Administrator / Quality Control, Instruktur dan peserta pendidikan dan latihan(karyawan) untuk mengoperasikan system ujian online yaitu:

Prosedur administrator / Quality Control) mencakup:

1. Menambah User Login instruktur, karyawan

2. Menampilkan Home

3. Menampilkan menu nilai peserta ujian

4. Melakukan Edit Tambah dan Hapus data user

5. Melakukan Edit Tambah dan Hapus kategori

6. Melakukan Edit Tambah dan Hapus soal

7. Melakukan Edit Tambah dan Hapus bank soal

8. Logout

Prosedur instruktur meliputi:

1. Melakukan Login

2. Menampilkan Home

3. Melakukan Input Soal, Input Jawaban Soal

4. Melihat nilai hasil ujian

5. Logout

Prosedur karyawan antara-lain:

1. Melakukan Login

2. Menampilkan Home 
3. Mengisi/menjawab soal

4. Melihat nilai

5. Logout

\section{Diagram Rancangan Sistem Ujian Online}

\section{Use Case Diagram Sistem Ujian Online}

Use case diagram menggambarkan fungsi tertentu suatu sistem berupa komponen kejadian atau kelas.[8] Yang ditekankan adalah "apa" yang diperbuat sistem, bukan "bagaimana" sebuah sistem bekerja. Urutan langkah-langkah yang secara tindakan saling terkait(scenario) baik terotomatisasi maupun secara manual untuk tujuan melengkapi satu tugas bisnis tunggal .[9] Sebuah use case mempersentasikan sebuah interaksi antara actor dengan sistem.

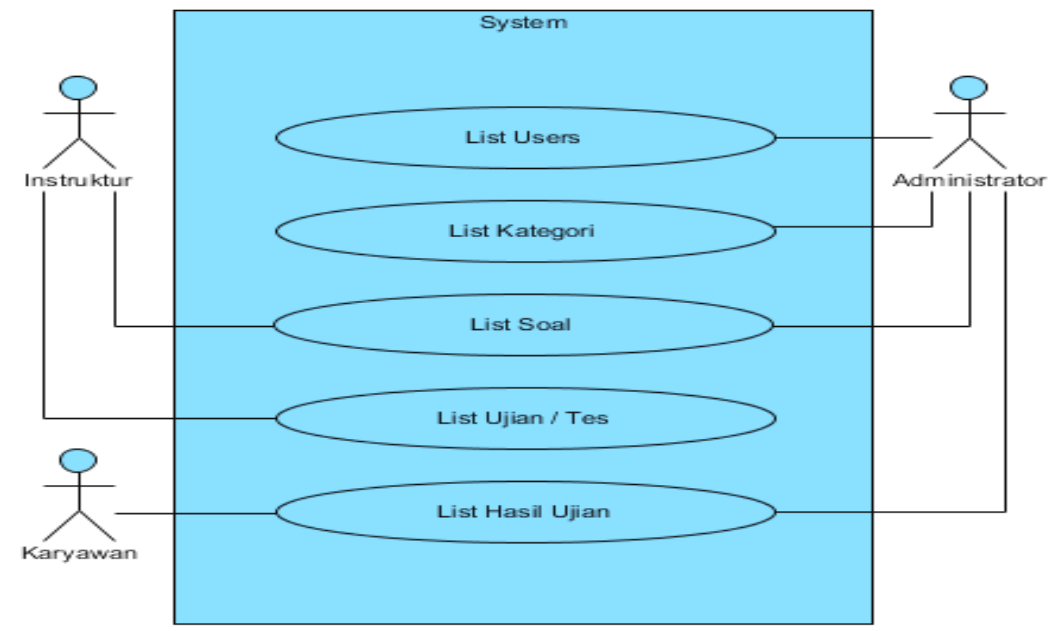

Gambar 1. Use Case Diagram Sistem Ujian Online

Berdasarkan gambar 1 use case diagram di atas terdapat :

a. 1 (satu) System yang mencakup seluruh kegiatan ujian.

b. 3 (satu) Actor yang melakukan kegiatan.

c. 5 (dua) Use Case Diagram yang dilakukan actor

\section{Use Case Diagram Sistem Ujian Online Pada Administrator}

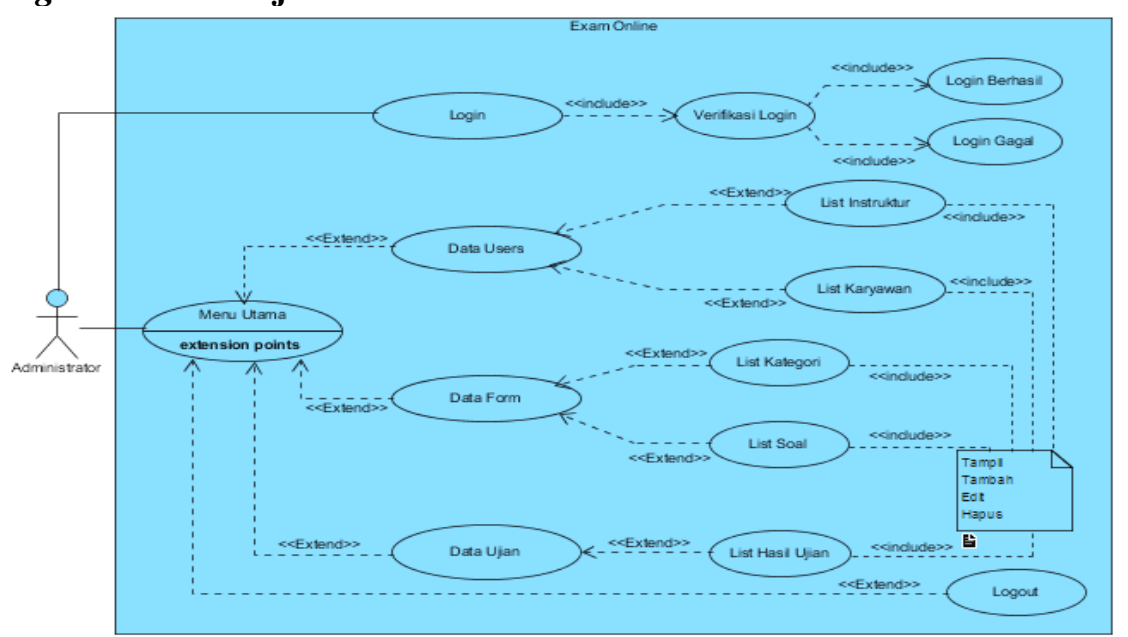

Gambar. 2 Use Case Diagram Administrator Sistem Ujian Online

Berdasarkan gambar 2 use case diagram administrator di atas,terdapat:

a. 1 (satu) System yang mencakup seluruh kegiatan ujian online.

b. 1 (satu) Actor yang melakukan kegiatan. 
c. 2 (dua) Use Case Diagram yang dilakukan actor.

d. 9 (sembilan) Extend yang ada pada menu.

e. 8 (delapan) Include yang merupakan masukan dari sub sistem.

f. 1 (satu) Note yang merupakan sumber daya komputasi.

\section{Use Case Diagram Sistem Ujian Online Pada Instruktur}

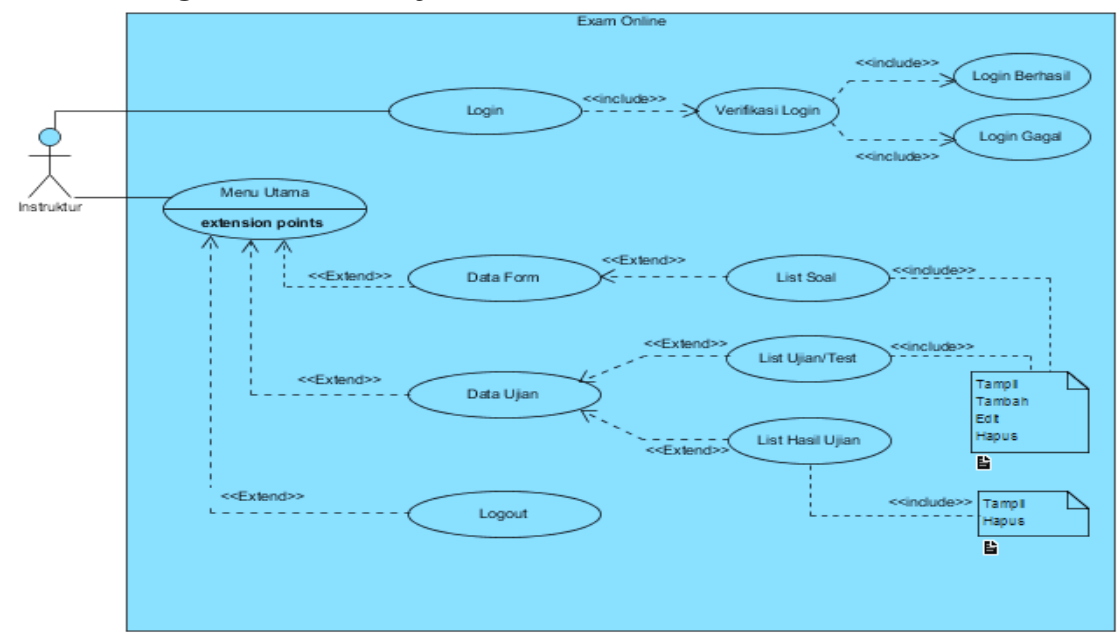

Gambar 3. Use Case Diagram Instruktur

Berdasarkan gambar 3 use case diagram instruktur di atas, terdapat :

a. 1 (satu) System yang mencakup seluruh kegiatan ujian online.

b. 1 (satu) Actor yang melakukan kegiatan.

c. 2 (dua) Use Case Diagram yang dilakukan actor.

d. 12 (dua belas) Extend yang ada pada menu.

e. 11 (sebelas) Include yang merupakan masukan dari sub sistem.

f. 1 (satu) Note yang merupakan sumber daya komputasi.

\section{Use Case Diagram Sistem Ujian Online Pada Karyawan}

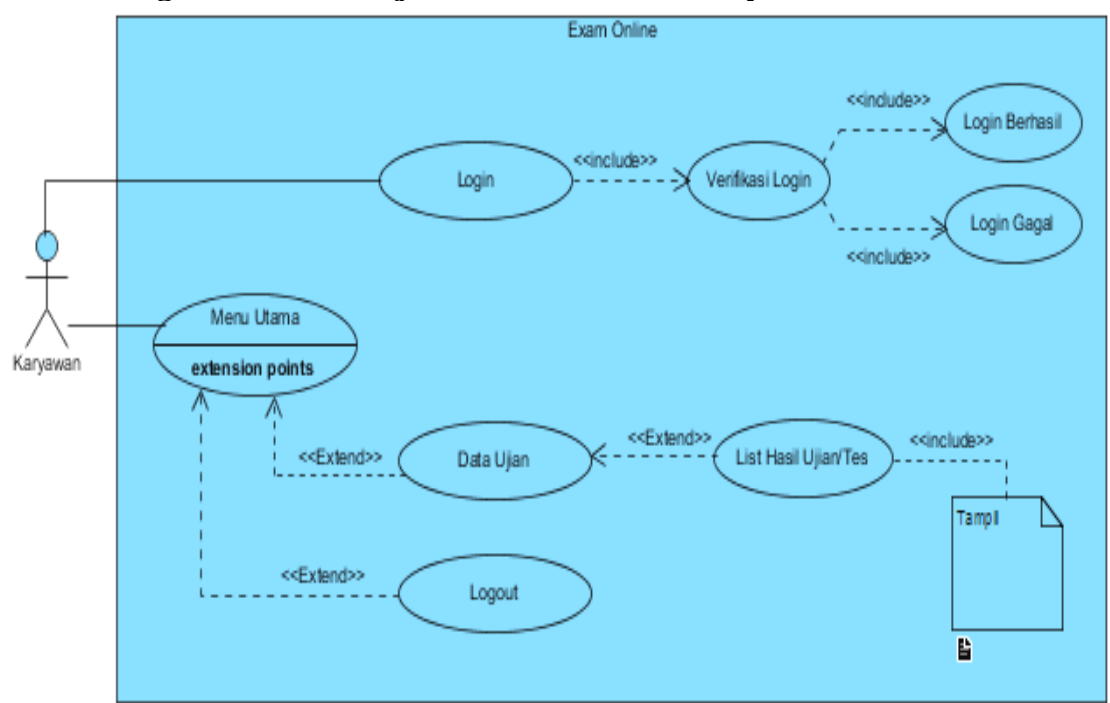

Gambar 4. Use Case Diagram Sistem Ujian Online pada Karyawan

Berdasarkan gambar 4 use case diagram karyawan di atas, terdapat :

a. 1 (satu) System yang mencakup seluruh kegiatan ujian online.

b. 1 (satu) Actor yang melakukan kegiatan. 
c. 2 (dua) Use Case Diagram yang dilakukan actor.

d. 3 (tiga) Extend yang ada pada menu.

e. 4 (empat) Include yang merupakan masukan dari sub sistem.

f. 1 (satu) Note yang merupakan sumber daya komputasi.

\section{Activity Diagram Sistem Ujian Online}

Activity diagram lebih memfokuskan diri pada eksekusi dan alur sistema. Diagram ini memodelkan software dan memodelkan bisnis. Diagram ini juga menunjukkan aktivitas sistem dalam bentuk kumpulan aksi-aksi.[10]

Diagram ini menggambarkan berbagai alur aktivitas dalam sistem yang sedang berjalan, bagaimana masing-masing alur berawal, decision yang mungkin terjadi, dan bagaimana mereka berakhir. Activity diagram juga dapat menggambarkan proses paralel yang mungkin terjadi pada beberapa eksekusi.

Activity diagram merupakan state diagram khusus, di mana sebagian besar state adalah action dan sebagian besar transisi di-trigger oleh selesainya state sebelumnya (internal processing). Oleh karena itu activity diagram tidak menggambarkan behaviour internal sebuah sistem melainkan interaksi antar subsistem secara ekstrak tetapi lebih menggambarkan proses-proses dan jalur aktivitas dari level atas secara umum.

\section{Activity Diagram Sistem Ujian Online}

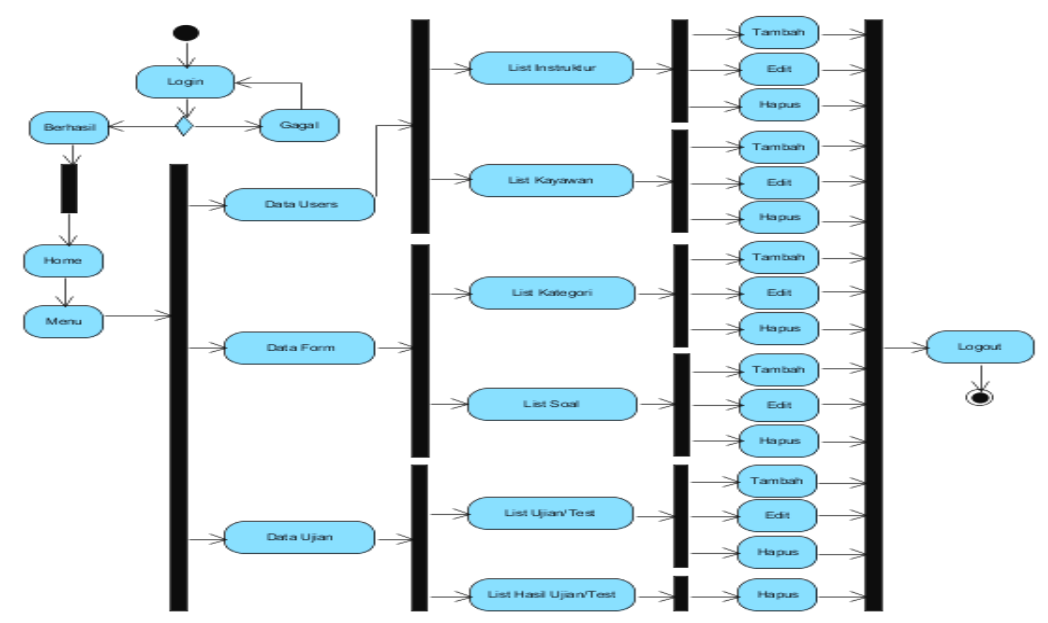

Gambar 5. Activity Diagram Sistem Ujian Online

Berdasarkan pada gambar 5 activity diagram di atas terdiri dari:

a. 1 (satu) Initial node yang merupakan awal kegiatan.

b. 31 (tiga puluh satu) Action, State dari sistem yang mencerminkan eksekusi dari suatu aksi.

c. 1 (satu) Final node sebagai object yang diakhir.

\section{Class Diagram Sistem Ujian Online}

Diagram kelas merupakan kumpulan-kumpulan kelas-kelas obyek. Oleh karena itu pengertian kelas sangat penting sebelum merancang diagram kelas.[9]

Diagram kelas (class diagram) sangat membantu dalam visualisasi kelas dari suatu sistem. Hal ini disebabkan karena class adalah deskripsi kelompok objek-objek dengan atribut (property) dan relasi yang sama. disamping itu class diagram bisa memberikan pandangan global atas sebuah sistem. Hal tersebut tercermin dari classclass yang ada dan relasinya satu dengan yang lain. Pada gambar 6 di bawah ini menunjukkan class diagram Ujian Online pada PT. Angkasa Pura II (Persero). 


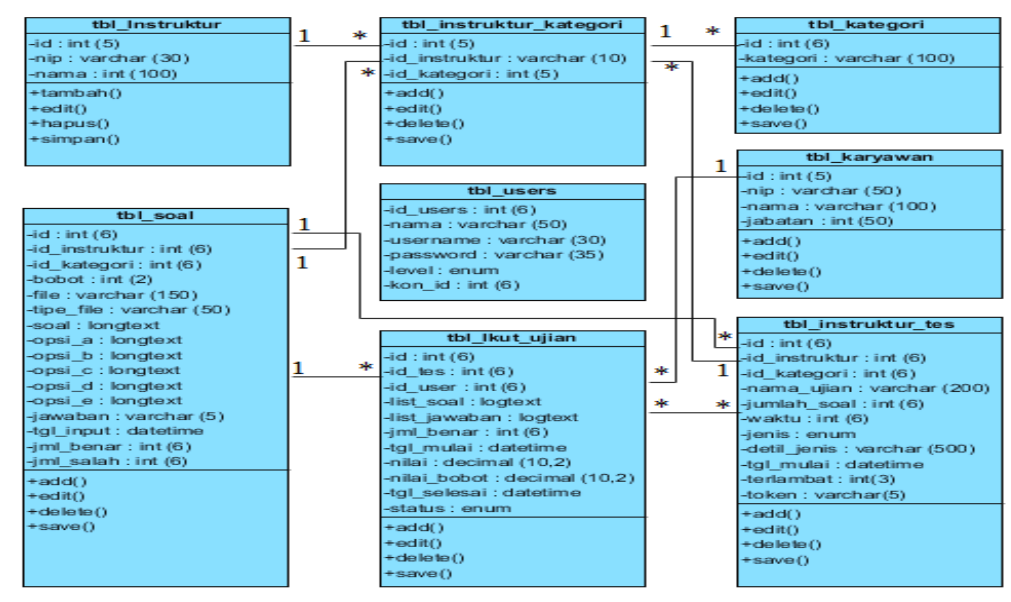

Gambar 6. Class Diagram Sistem Ujian Online

\section{IMPLEMENTASI}

\section{Rancangan Interface Sistem Ujian Online}

Rancangan interface sistem ujian online ini terdapat beberapa interface antara-lain : Tampilan Halaman Login, Tampilan Halaman Home Admin, Tampilan Menu Instruktur, Tampilan Menu Karyawan, Tampilan Menu List Data Ujian, Tampilan Menu Soal, Tampilan Menu Hasil Ujian, dan Tampilan Laporan Hasil Ujian.

Tampilan Halaman Login yaitu menampilkan halaman login bagi para pengguna-peserta pendidikan dan instruktur--untuk memasukkan user id dan password. Hal ini untuk mencegah dari oknum tertentu yang memanfaatkan system ini untuk kepentingan pribadi. Tampilan halaman ini dapat dilihat pada gambar 7 di bawah ini.

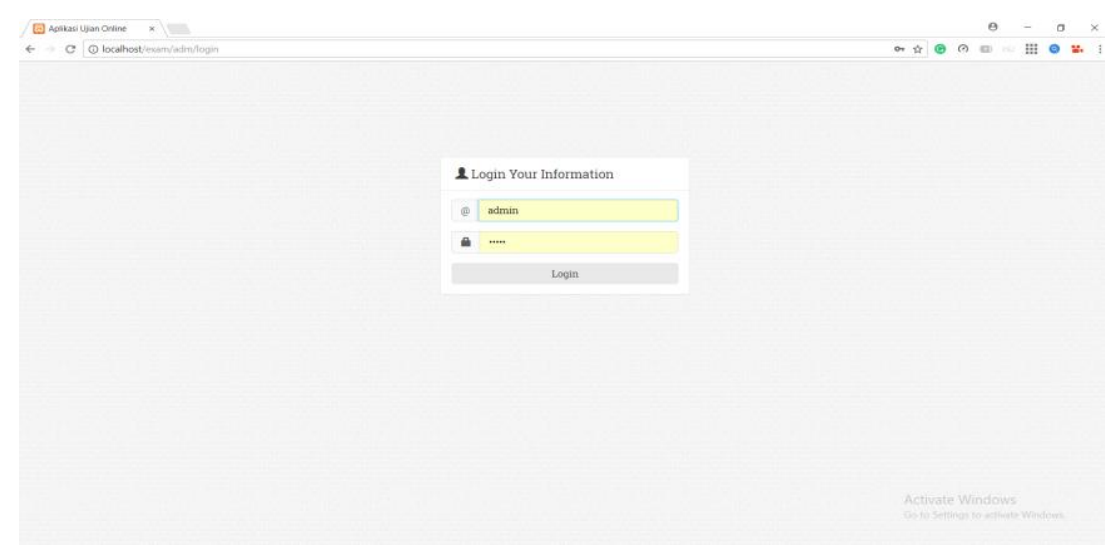

Gambar 7. Tampilan Halaman Login

Tampilan Halaman Home Admin yaitu menampilkan halaman home admin sehingga memudahkan bagi admin sistem mengenali halaman ini untuk bisa melakukan login ke sistem. Tampilan halaman ini dapat dilihat pada gambar 8 di bawah ini. 


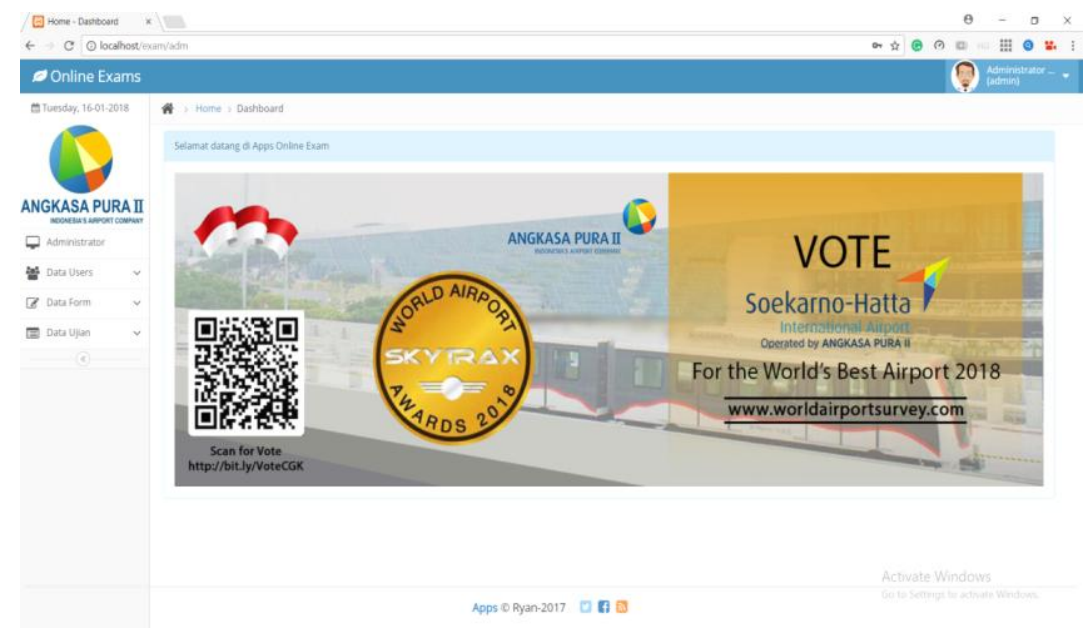

Gambar 8. Tampilan Halaman Home Admin

Tampilan Menu Instruktur adalah untuk menampilkan halaman menu instruktur sehingga instruktur dapat memahami fasilitas apa saja yang tersedia pada sistem (lihat gambar 9 di bawah ini).

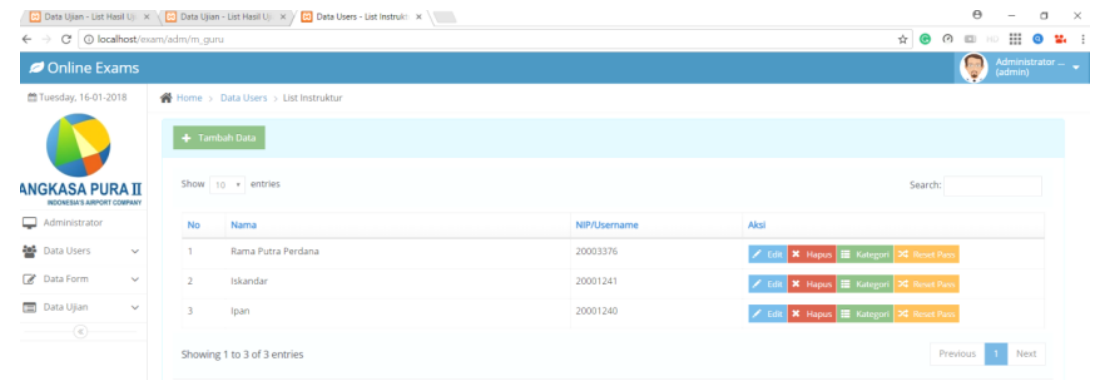

Gambar 9. Tampilan Menu Instruktur

Tampilan Menu Karyawan yaitu untuk menampilkan fasilitas apa saja yang tersedia pada halaman ini bagi para pengguna peserta pendidikan sehingga mereka mengenali fasilitas yang tersedia pada sistem. (lihat gambar 10).

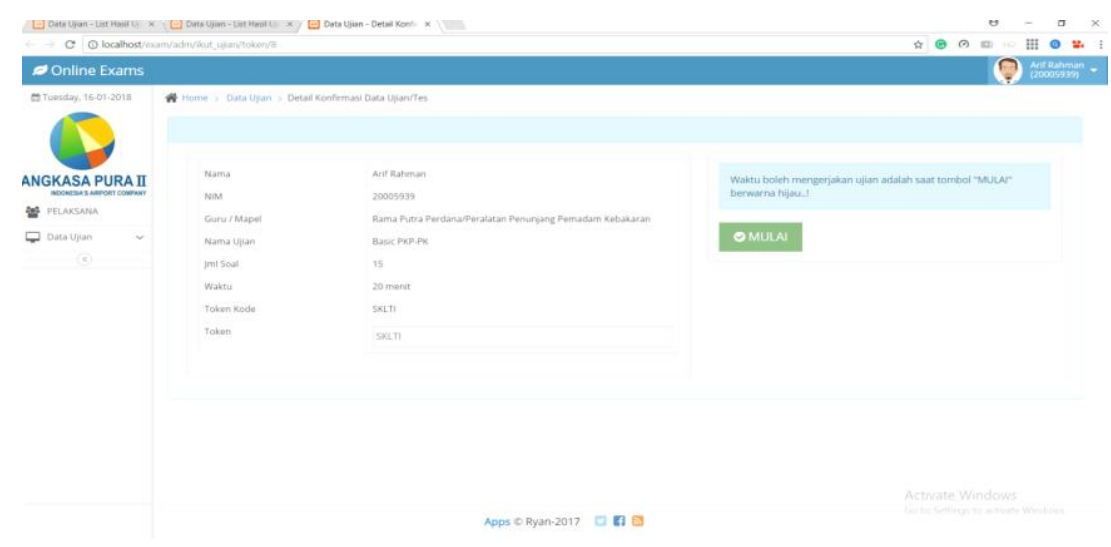

Gambar 10. Tampilan Menu Karyawan 
Tampilan Menu List Data Ujian yaitu untuk menampilkan list data ujian yang tersedia sehinga pengguna dapat memilih data ujian yang mana bisa dilaksanakan. Tampilan menu ini dapat dilihat pada gambar 11 di bawah ini.

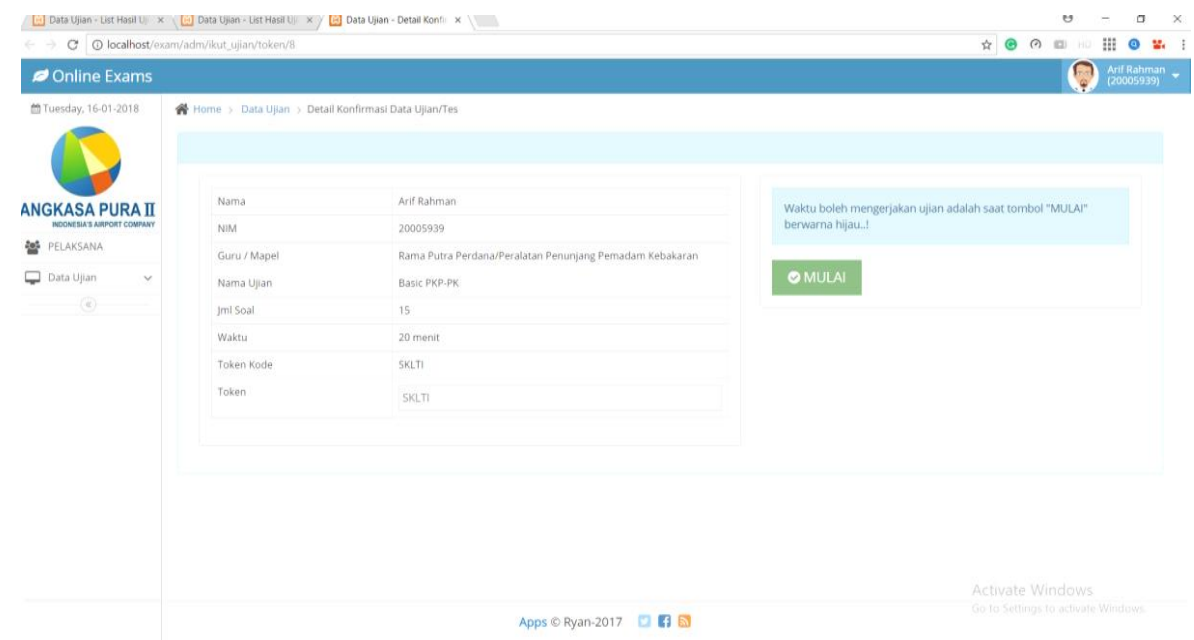

Gambar 11. Tampilan Menu List Data Ujian

Tampilan Menu Soal yaitu untuk menampilkan halaman menu soal seperti terlihat pada gambar 12 di bawah ini. Halaman ini memberikan informasi bagi pengguna-peserta pendidikan--soal-soal apa saja yang harus diselesaikan dalam jangka waktu tertentu sehingga peserta pendidikan dapat segera menyelesaikannya.

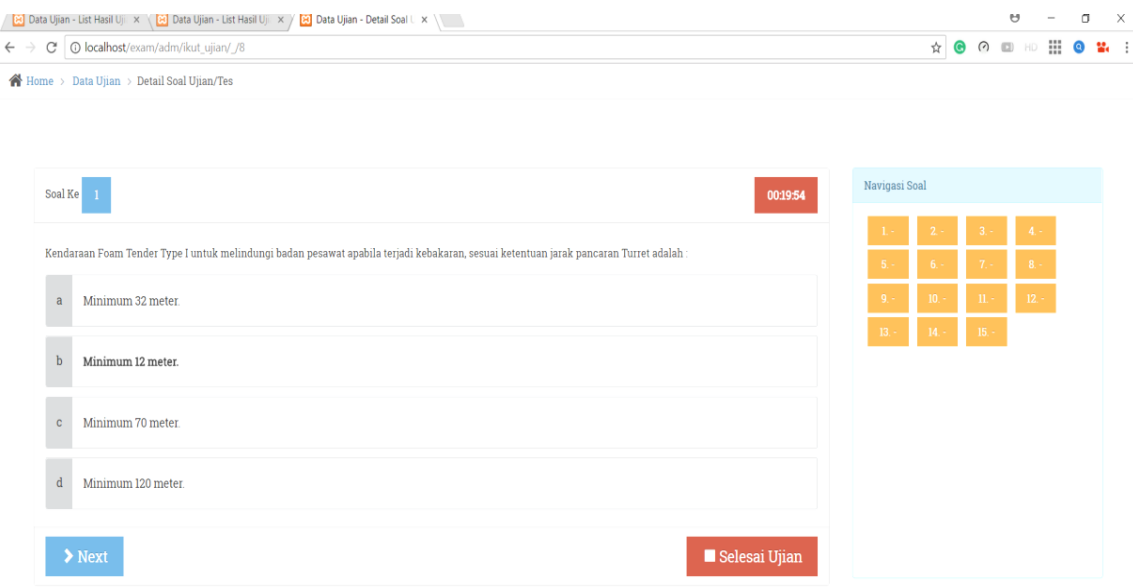

1

Gambar 12. Tampilan Menu Soal

Tampilan Menu Hasil Ujian yaitu untuk menampilkan hasil ujian yang telah diselesaikan oleh peserta pendidikan. Halaman ini memberikan informasi hasil ujian yang telah diselesaikan oleh mereka dengan nilai tertentu dan pada waktu tertentu. Tampilan halaman ini dapat dilihat pada gambar 13 di bawah ini. 


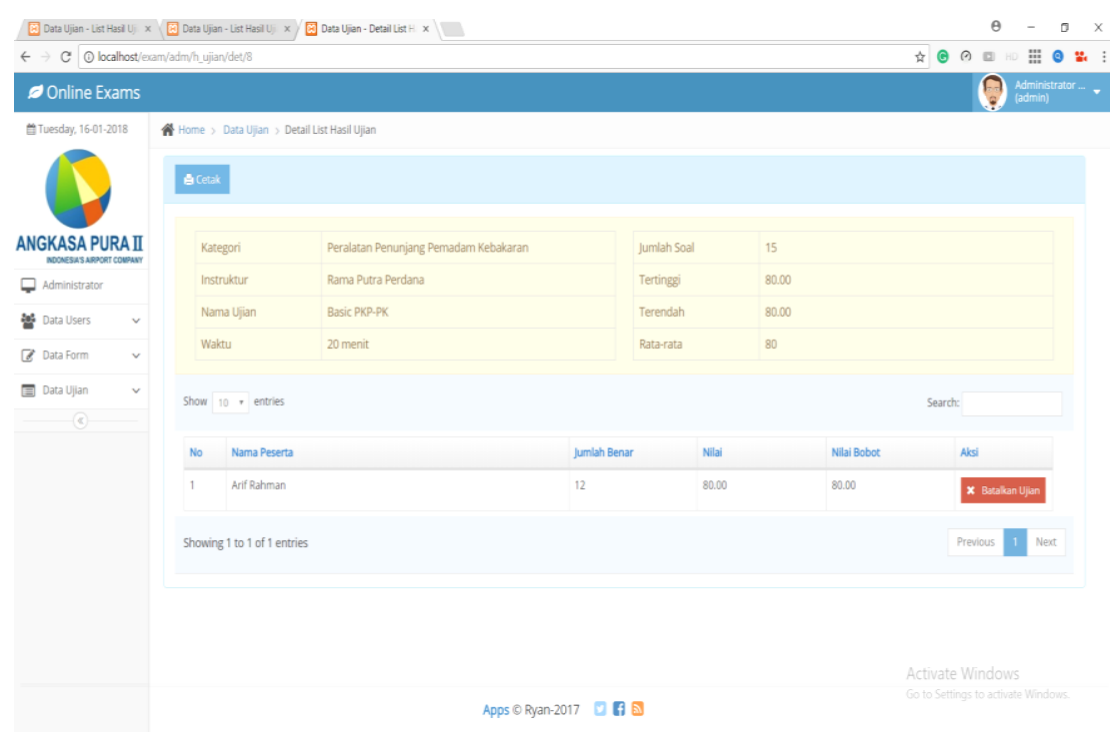

Gambar 13. Tampilan Menu Hasil Ujian

Tampilan Laporan Hasil Ujian yaitu untuk menampilkan laporan rangkuman hasil ujian yang telah dilaksanakan. Tampilan ini dapat dilihat pada gambar 14 di bawah ini.

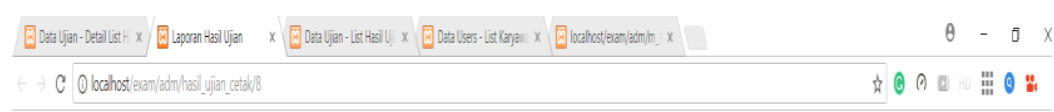

Laporan Hasil Ujian

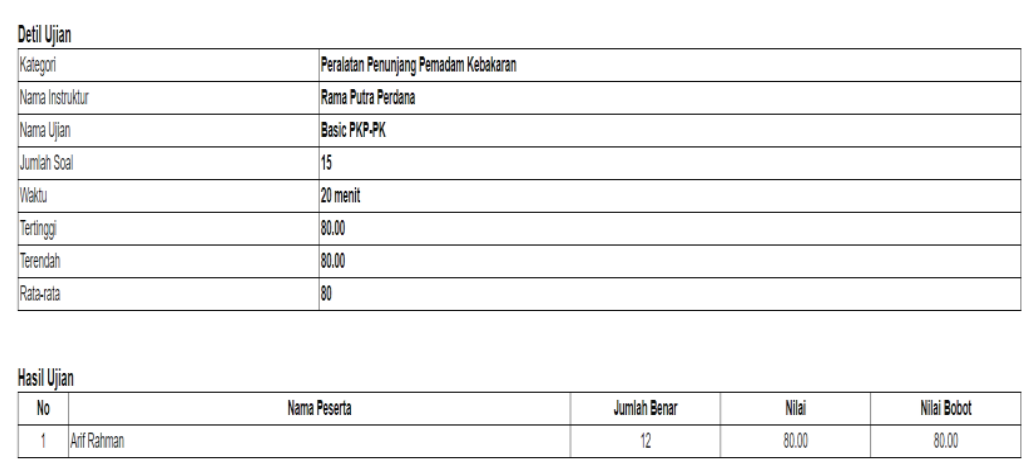

Gambar 14. Tampilan Menu Laporan Hasil Ujian

\section{KESIMPULAN}

Hasil pembahasan di atas, dapat disimpulkan terdapat beberapa hal antara-lain:

1. Untuk sistem ujian lisensi yang berjalan saat ini dilakukan dengan cara manual menggunakan kertas dan lembar jawaban kosong.

2. Kendala dalam sistem ujian yang berjalan saat ini membuat instruktur harus menambah jam kerja untuk membuat dan menilai soal ujian para karyawan secara manual.

3. Aplikasi ini memiliki beberapa kelebihan dibandingkan dengan sistem lama. Berikut ini beberapa kelebihan dari aplikasi ujian online, yaitu:

a. Proses ujian bisa lebih cepat dan efisien karena tidak memerlukan media alat tulis seperti ujian konvensional.

b. Mempersempit kecurangan dalam proses ujian. 
c. Karyawan dan instruktur bisa mengecek nilai secara langsung.

d. Memudahkan instruktur melakukan pengecekan jawaban ujian.

\section{SARAN}

Masukan untuk perancangan aplikasi sistem ujian online lisensi PK-PPK ini pada PT. Angkasa Pura II (Persero) antara-lain:

1. Perlu adanya evaluasi dan pengembangan-pengembangan sistem, agar sistem bisa menjadi lebih baik dan mempermudah kinerja perusahaan.

2. Adanya pelatihan-pelatihan atau sosialisi kerja kepada user, dan perlu juga diadakan evaluasi masukan untuk penyempurnaan sistem yang ada sesuai kebutuhan $u s e r$.

\section{DAFTAR PUSTAKA}

[1] Prastomo, Andi. 2014. "Prototipe Sistem E-Learning dengan Pendekatan Elisitasi Dan Framework Codeigniter: Studi Kasus SMP Yamad Bekasi”. Faktor Exacta : ISSN: 1979276X.

[2] Pressman, Roger S..2012.Rekayasa Perangkat Lunak - Pendekatan Praktisi. Terjemahan Buku 1. Jogyakarta: Andi Offset.

[3] Neil, J Salkind. 2013. Tests and Measurement for people who (Think They) Hate Tests and Measurement diakses dari http://eprints.uny.ac.id/ 45824/1/13501247003\%20\%EF\%80\%A7\%20FEBRIANTO.pdf. pada tanggal 7 november 2017 jam 21.15 WIB.

[4] Oduntan O.E., Ojuawo O.O. and Oduntan E.A. 2015. "A Comparative Analysis of Student Performance in Paper Pencil Test (PPT) and Computer Based Test (CBT) Examination System". Diakses dari https://pdfs.semanticscholar.org/f17a/f46973871d596f54d6a6a578ef 6d7d7a7c3c.pdf. pada tanggal 10 november 2017 pukul 07.12 WIB

[5] Andy, Krisianto. 2014. Internet untuk pemula. Hal 1. Jakarta: PT Elex Media Komputindo.

[6] Enterprise, Jubilee. 2014. Belajar Komputer Dari Nol. Yogyakarta: Elex Kidz Book.

[7] Glosarium bpk.go.id diakses tanggal 8 November 2018.

[8] Pilone, Dan, Neil Pitman.2005. bab 7.1. UML Bible. Indiana:John Wiley \& Son.

[9] Whitten, Jeffery L. et all.2004. Metode Desain dan Analysis Sistem(terjemahan).hal 258, 410. Yogyakarta:Andi Offset.

[10] Prabowo Pudjo Widodo dan Herlawati. 2011. Menggunakan UML. Hal 143. Bandung: Penerbit Informatika. 